\title{
Analysis of Replicability of Conservation Actions across Mediterranean Europe
}

\author{
Daniel Ibarra-Marinas, Francisco Belmonte-Serrato (D), Ramón García-Marín (D) \\ and Gustavo Ballesteros-Pelegrín *(D)
}

Department of Geography, Campus La Merced, University of Murcia, 30001 Murcia, Spain; adaniel.ibarra@um.es (D.I.-M.); franbel@um.es (F.B.-S.); ramongm@um.es (R.G.-M.)

* Correspondence: gabp1@um.es

check for

updates

Citation: Ibarra-Marinas, D.;

Belmonte-Serrato, F.; García-Marín,

R.; Ballesteros-Pelegrín, G. Analysis

of Replicability of Conservation

Actions across Mediterranean Europe.

Land 2021, 10, 598. https:/ / doi.org/

10.3390/land10060598

Academic Editors: Mónica de

Castro-Pardo, Joao C. Azevedo and

Pascual Fernández

Received: 9 April 2021

Accepted: 2 June 2021

Published: 4 June 2021

Publisher's Note: MDPI stays neutral with regard to jurisdictional claims in published maps and institutional affiliations.

Copyright: (c) 2021 by the authors. Licensee MDPI, Basel, Switzerland. This article is an open access article distributed under the terms and conditions of the Creative Commons Attribution (CC BY) license (https:/ / creativecommons.org/licenses/by/ $4.0 /)$.

\begin{abstract}
In the Regional Park of Las Salinas and Arenales of San Pedro del Pinatar, in southeastern Spain, an environmental restoration and conservation project is being developed whose principle actions include adaptation of hillocks with a saline substrate to improve the reproduction habitat of aquatic birds and increasing the production of salt, dune restoration and conservation, protection of the first dune ridge through the collection of seagrass tops, and designing and implementation of a salt quality seal, which may be useful for reproduction in other sites in the Natura 2000 network, especially in the European Mediterranean area and in the Black Sea environment. The objective of this research study was to analyse and locate the sites that could possibly replicate the actions of the project. In order to do this, spatial databases were used from the Natura 2000 network, salt flats, and marshes as well as Ramsar sites and SPAMI sites, and from them a shape file of points was created in the places with the presence of maritime dunes associated with marsh systems/salt flats. One hundred thirty-one sites in the Natura 2000 network were located, of which in 105 cases, one or more of the four actions considered in this research study can be replicated. Of these, 24 cases have active or recently abandoned salt flats in which the two main actions of the project can be replicated, and 11 of these sites meet characteristics for the replicability of the four actions, of which three have not been implemented by the LIFE projects developed on those sites.
\end{abstract}

Keywords: environmental restoration; conservation; replicability; Natura 2000 network; coastal salt flats; wetlands; dune systems, natural parks

\section{Introduction}

Wetlands are some of the most productive and ecologically valuable ecosystems [1]. According to Barbier et al. [2], wetlands perform critical ecosystem functions and services as stopovers for migratory birds, critical nursing grounds, production of raw materials and food, maintenance of coastal fisheries, coastal protection, erosion control, and carbon sequestration. Despite their importance and increased efforts to preserve them, wetlands are still being transformed for urban development and other activities like aquaculture at a rapid pace [3]. Some authors indicate the existence of a greater awareness of the importance of wetland ecosystem functions as well as growing concerns among environmentalists [4], and this growing restlessness has resulted in a range of conservation and management approaches [5-8]. These approaches include policy instruments at different administrative levels [4] such as implementing various wetland restoration programs [9] in order to mitigate the negative impacts of socioeconomic development on these unique ecosystems $[10,11]$ and provide resources and monetary incentives for their conservation [12,13].

There are numerous highly productive wetlands with varied ecosystem services [14] affected by anthropogenic stress due to the large coastal population $[15,16]$. One of the main problems encountered affects the reduction and disappearance of biological diversity, a consequence of habitat modification, usually due to conversion and degradation of 
wetlands [17]. The objectives in these cases are to promote the reduction of ecosystem stress through the identification of environmental problems in a diagnostic analysis, then establishing strategic action programs [18]. Normally, among the programmed strategies, public awareness campaigns are carried out to increase environmental awareness directed at different levels of society [19-21], including parliamentary workshops for politicians, training events for local government officials, scientific conferences, and the participation of scientists in research and reporting to university and high school students, sometimes conducting environmental camps [22].

Networks are also usually created and associations that collaborate and work with environmental organizations and NGOs $[23,24]$ carry out biodiversity assessments that have contributed to scientific development toward the improvement of densities, distributions, and genetic diversity of populations of endangered and endemic species as well as favourable actions for the maintenance of habitats according to norms and regulations and a reduction of the risk of introduced species. The final goal of these programsis to ensure that biodiversity remains present to benefit future generations.

There seems to be, therefore, an urgent need to develop and improve ecological restoration methods to rehabilitate or restore degraded coastal wetlands. And in this context, the LIFE Project [25] that we describe below is framed.

Scholars, practitioners, and environmentalists are increasingly supportive of collaborative, ecosystem-based approaches to coastal resource management [26]. However, few researchers have focused their attention on trying to promote satisfactory improvement actions in wetlands and salt ponds that can be used in other places with similar environmental characteristics.

In this sense, the objective of this research study was to analyse and locate the sites that could possibly replicate the actions of the project, that is, those places with similar characteristics to the study area (European Mediterranean coastal environments) and with a greater possibility of being able to successfully transfer the management and tasks or studies developed in the Regional Park of Las Salinas and Arenales of San Pedro del Pinatar.

\section{The Project and Study Area}

\subsection{The Project}

A project is being developed in the Regional Park of Arenales and Salinas of San Pedro del Pinatar (southeastern of Spain) (LIFE-Salinas) in which the field of nature conservation, restoration, and improvement in the production of salt and its interrelation with the tourism industry is being studied.

The main objective is the conservation of the Audouin's gull (Larus audouinii) and the following priority habitats: $1510 *$, Mediterranean saline steppes (Limonietalia); and 2250 *, littoral dunes with Juniperus spp. in the Site of Community Importance (SCI) and Special Protection Areas for Birds (SPAs) ES0000175 "Salinas y Arenales de San Pedro del Pinatar". On the other hand, as an added value, the project will allow favouring habitats to be included in the Habitat Directive and increase the integration and ecosystem cohesion of the SCI and SPAs. Likewise, as an added objective, the project aims to facilitate the transfer and replicability of some of its main actions outside its territorial scope (other regions or countries).

This project is expected to increase habitats of special interest after the construction of $1800 \mathrm{~m}$ of new salt mines and the repair of other mines, covering them with a substrate of lagoons that heat the ground and prevent the development of vegetation. The recovery of the water circuit of the Coterillo lagoon (saline wetland) will allow for the recovery of endangered species, such as the Spanish tooth carp (Aphanius iberus), and will expand the feeding area of the Audouin gull. It is also expected to halt erosion in the adjacent La Llana beach and recover and protect the ridge of dunes in its first $500 \mathrm{~m}$ south of the port of San Pedro del Pinatar, an important areaof habitat for 1510 Mediterranean saline steppes. Stopping the erosion of the dune system of Playa de la Llana will improve the conservation of priority habitat $1510^{*}$ and benefit 10 other habitats in Annex I of the Habitat Directive. 
In addition, the actions related to the improvement of the dune-beach system will make it possible to face the challenges of climate change (the rise in sea level and increase in the frequency of storms) and prevent Mediterranean waters from invading the salt lagoons adjacent to the colony of Audouin's gulls and other species.

The most transferable action of the project is the design and implementation of a quality and environmental protection certificate for the salt produced in the Mediterranean salt flats that are included in the Natura 2000 network.In the following link all the information on this project can be found: https:/ /lifesalinas.es/en/home/ (accessed on 31 May 2021).

\subsection{Study Area}

The project intervention area is limited to the Regional Park of the Salinas and Arenales de San Pedro del Pinatar (Figure 1) in the extreme north of the coast of the Region of Murcia (southeastern Spain) within the municipality of San Pedro del Pinatar, its northern limit coinciding with the provincial limit between the provinces of Murcia and Alicante and in its southern limit borders the area called Las Encañizadas, an area of natural communication between the Mediterranean and the Mar Menor, with very shallow depths $(50-100 \mathrm{~cm})$ where a traditional method of fishing called Encañizada is still actively used. This space is about $65 \mathrm{~km}$ long and $1.4 \mathrm{~km}$ at its widest part, and geomorphologically constitutes the northern closure of the La Manga del Mar Menor spit, a $22 \mathrm{~km}$ long strip that separates the Mediterranean from the coastal lagoon called the Mar Menor (the largest salt lake in Europe). This lagoon is the remnant of an old bay, wider than the current lagoon, filled over the last 10 million years [27]. The closure of the spit has been occurring since the beginning of the Quaternary period via sediments from the mouth of the Segura River, transported south by the littoral current that is cut off in Cabo de Palos. The sediments were deposited around some islands of volcanic origin, more or less aligned in a north-south direction (Calnegre and Monte Blanco), and on the Tertiary sandstone reefs of Pedrucho, Estacio and Punta de Algas [28]. The almost definitive closure already occurred about 2000 years ago, but communication with the Mediterranean is maintained through artificial channels or natural gullies [29].

It is aprotected natural area made up of a complex set of wetlands, occupied mainly by extensive areas destined for salt exploitation and adjacent ecological systems of great interest. There is an important biota adapted to the presence of water $[30,31]$, and if we look at the definition of wetlands established at the Ramsar Convention, which states that "For the purposes of this Convention, wetlands are extensions of areas of marsh, fen, peatland, or water, whether natural or artificial, permanent or temporary, with water that is static or flowing, fresh, brackish, or salt, including areas of marine water the depth of which at low tide does not exceed six meters", this natural space can be considered to be a unique wetland.

It was declared a Nature Park, or Protected Nature Reserve, in 1985, with a total area of 856 hectares, and in 1992 it acquired the status of Regional Park. Since 1994 it has been included in the List of Wetlands of International Importance (according to the Ramsar Convention). The importance of this wetland as a nesting, wintering, and migration site for a large number of migratory birds, such as flamingos, avocets, stilts, etc., led to it being declared a Special Protection Area for Birds (SPAB) in 1998 (Resolution of 13 October 1998; BORM n 246 of 24 October 1998), with an area of 841.75 ha, thus becoming part of the Natura 2000 network of the European Union.

As an integral part of the Mar Menor, it is also a Specially Protected Area of Mediterranean Importance (SPAMI). In addition, due to its fauna values (reptiles such as the red-tailed lizard, the Pimelia sp. beetle, endangered fish such as the Spanish tooth carp, small crustaceans such as Artemia sp., and various species of bats, in addition to the aforementioned birds) and flora (tamarisks, salicornias, marjoram trees and rushes in the salt marshes, and Aleppo pine, mastic, black hawthorn, birds-foot-trefoil, lily, thistle or sea caterpillar, on the dune ridge), and practically coinciding with the SPAB space, it was also declared a Place of Community Importance. 


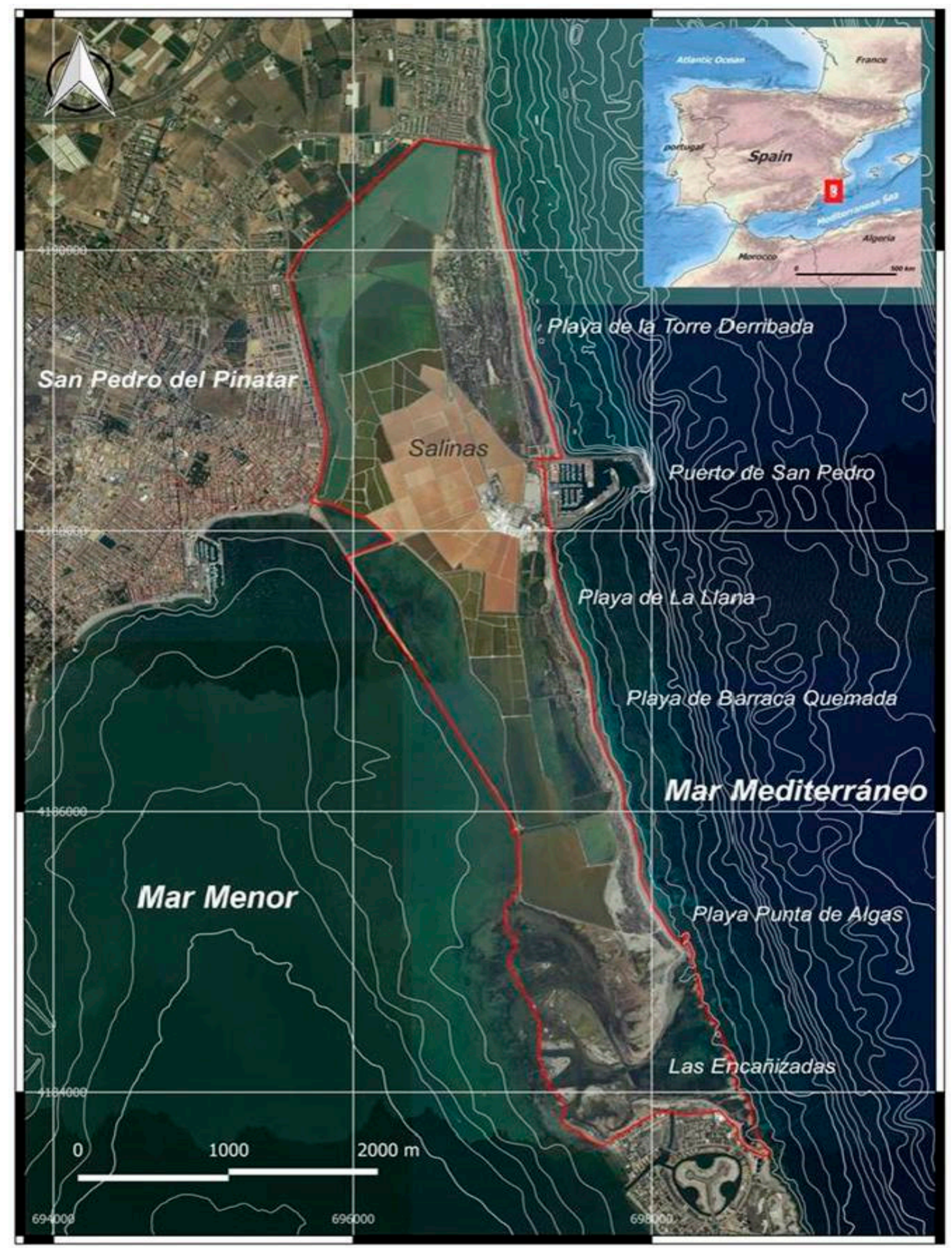

Figure 1. Area of study. Source: own elaboration from a PNOA image.

The majority of the park, about 500 hectares of the 856 total, is occupied by the premises of the salt mine, consisting of three types of salt ponds and the processing facilities of the Spanish company Salinera Española, owner of the salt works prior to the delimitation of the Maritime Public Domain and current operating owner. In front of the Mediterranean-facing side of the park, between $0.50 \mathrm{~m}$ and $30 \mathrm{~m}$ deep, there are extensive meadows of Posidonia oceanica, a seagrass exclusive to the Mediterranean. Posidonia, an important primary producer, provides a high amount of oxygen and regulates $\mathrm{CO}_{2}$. Furthermore, due to its positioning parallel to the coast, it forms an effective barrier that considerably reduces and 
dissipates wave energy [32]. Likewise, it traps the sand moved by the waves, preventing its transport beyond the closing depth of the submerged beach. On the other hand, the dead parts of the plant are transported by the waves to the beach, where they end up forming important accumulations of banquettes that serve as a refuge and nesting place for some birds, such as the black-footed plover (Charadrius alexandrinus), in addition to being food for many species of crustaceans and molluscs, which, in turn, feed the many seabirds in the area. Likewise, after being removed from the beach during the tourist season, it has been used to protect the dune ridge from the onslaught of waves in storms with winds coming from the east, with the dead parts of the plant accumulating on the dune front.

\section{Materials and Methods}

The study of the replicability and transferability of the project actions required the analysis and extrapolation of the environmental characteristics of the study area. Although most of the actions can be carried out in places with characteristics that are very different from the target area of the project. An attempt was made to exclusively identify areas that may have similar attributes from a conservation point of view, for which the analysis of spatial data has been necessary in order to optimize the choice of potential areas of replicability and transferability of some of the improvement and conservation actions contemplated in the project. In particular, the specific actions subject to transferability would be the following:

(a) The adaptation of hillocks with saline substrate: These actions are aimed at improving the reproduction habitat of aquatic birds and increasing the production of salt. This action has a twofold objective: (i) on the one hand, the adaptation of hillocks with saline substrate aims to increase the production of salt by $3 \%$, since it is intended to repair the deteriorated hillocks and build new ones to expand the circulation circuit of the water, which will accelerate heating; (ii) on the other, it represents an improvement in the nesting conditions of Larus audouinii, since it aims to increase the nesting habitat of this and other species in Annex I of the Birds Directive by $17 \%$ (Recurvirostra avosetta, Charadrius alexandrinus, Gelochelidon nilotica, Sterna hirundo, Sternula albifrons, and Sterna sandvicensis). At the end of the 1990s, only two colonies of Larus audouinii made up $85 \%$ of its world population. The most important was located in the Ebro Delta, with $60 \%$ of the world population [33], and the second largest colony was in the Chafarinas Islands, which had $25 \%$ of the total population. In recent decades, and despite the increase in breeding pairs, the wintering population of Larus audouinii has been reduced and dispersed [34]. The survival of the chicks depends on several factors such as the quality of the parents, the availability of food, the hatching order, the rates of predation, diseases, and climatic and habitat conditions [35-39]. Despite the variety of spaces used for breeding, both in the Ebro Delta and in the Salinas and Arenales Regional Park of San Pedro del Pinatar, the species Larus audouinii selects the hillocks of the salt ponds as habitats. A very favourable habitat is sandy saline patches and sandy areas without vegetation or with a moderate vegetation cover. The high salt content of the salt substrate used in this action favours this type of condition, and the correct circulation of the water in the saltworks will allow for the expected increase in production. For the selection of spaces, three minimum criteria have been considered: that the area is Mediterranean, that it is included in the Natura 2000 network, and that it has an area of artificial salt marshes/salt marshes.

(b) Dune restoration and conservation: The objective of this action is to stabilize the dunes located in the first $500 \mathrm{~m}$ at sea level of the Port of San Pedro del Pinatar (Figure 1) through the installation of sand collectors. This action will allow the reduction of wind speed, reducing the load of sand transported outside the dune-beach system, increasing the volume of deposits [40]. In addition, the action includes the elimination of the paths formed by the trampling of pedestrians along the dune system, for which perimeter fencing around those first $500 \mathrm{~m}$ of dune ridge from the north access will be 
made, which are the most deteriorated by the continuous passing of bathers during the summer months. The action will also include the recovery of the accumulated sand in one of the salt ponds and its transfer to the eroded area of the dune to restore its original state. The criteria for the selection of replicable spaces are the presence of dune-beach systems with the possibility of installing sand collectors, and the possibility of eliminating exotic species and introducing or revegetating with species included in Habitats of Community Interest (Annex I, Directive Habitats).

(c) Protection of the first dune ridge (the only ridge in some cases) through the collection on the dune front of seagrass tops (Posidonia oceanica, Zostera marina, Cymodocea nodosa, etc.) that accumulate on the beaches during coastal storms.

(d) Designing and implementation of a salt quality seal: To design and apply the methods, procedures, and criteria for obtaining a salt quality certificate for salt flats in the Natura 2000 network, compatible with the conservation of the territory and biodiversity.

\subsection{Data Sources}

Once the criteria for the actions with the possibility of replication were established, several spatial databases were used that contain the areas of the European Union with characteristics similar to those of the Salinas and Arenales Regional Park in San Pedro del Pinatar. The spatial data sources that were used are the following:

(a) Natura 2000 network: Provided by the European Environmental Agency, it contains, in shapefile format, the points and polygons of the spaces included in the Natura 2000 instrument, an ecological network of protected areas created to guarantee the survival of the most valuable species and habitats in Europe. Natura 2000 is based on the 1979 Birds Directive and the 1992 Habitats Directive. This version covers reporting since 2017. The database includes 27,738 sites within the scope of the European Union, with codes, types of places, and release dates.

(b) Salt flats and marshlands: This dataset shows the distribution of marshlands and salt flats (currently active or active until recently that still conserve salt structures) worldwide in polygon and point shapefile format. The database has been created and provided by the World Conservation Monitoring Center (UNEP-WCMC). All the sources used for its elaboration are included in the metadata [41] and include articles, reports, and documents reviewed by peers as well as databases created by nongovernmental and governmental organizations, universities, institutes of independent research, and researchers worldwide. In total, it outlines 26,398 places around the world, with relevant data such as altitude, area, type, name, and international codes.

(c) Ramsar sites: Provided by the Ramsar Sites Information Service, contained in CSV format, this dataset contains information on the criteria, name, region of location, ecosystems, main threats, and coordinates of the 2342 Ramsar sites around the world.

(d) SPAMIs: For the treatment of spatial data related to the SPAMI areas, two KML (Keyhole Markup Language) files were used, one of points and the other of polygons. The data were obtained through the Mediterranean Centre for Marine and Environmental Research (CMIMA).

(e) Dune-beach system zones: From the previous data sources, a shapefile of points was generated for the places with the presence of maritime dunes associated with the marshland/salt marsh systems. This database was created from a photointerpretation of the Mediterranean Coast.

The treatment of spatial data was carried out with the free software QGIS, an opensourcegeographic information system (GIS), licensed under the General Public License (GNU) that constitutes a project of the Open-Source Geospatial Foundation (OSGeo). QGIS enables the processing of spatial data in raster and vector file formats. The version used in the present study was 2.18. 


\subsection{Procedure}

From the coordinates of the Ramsar sites database, the CSV file was transformed into a shapefile. Once the databases shared the same format, the data was cross referenced in order to obtain the places that meet the requirements of the Salinas and Arenales of San Pedro del Pinatar Regional Park, located in the Mediterranean, which belong to the Ramsar Convention, and will be represented in the UNEP-WCMC database of salt flats and marshes and included in the Natura 2000 network of the European Union. The crossing of the three databases was carried out from the vector data management tools of the QGIS software. The expected results when carrying out this methodology were the location of spaces similar to the target area of the LIFE-Salinas Project.

Using aerial photographs, the elements of each location were located and information, such as the presence of dunes and activity or abandonment of the saltworks, wascollected through photointerpretation (Figure 2).

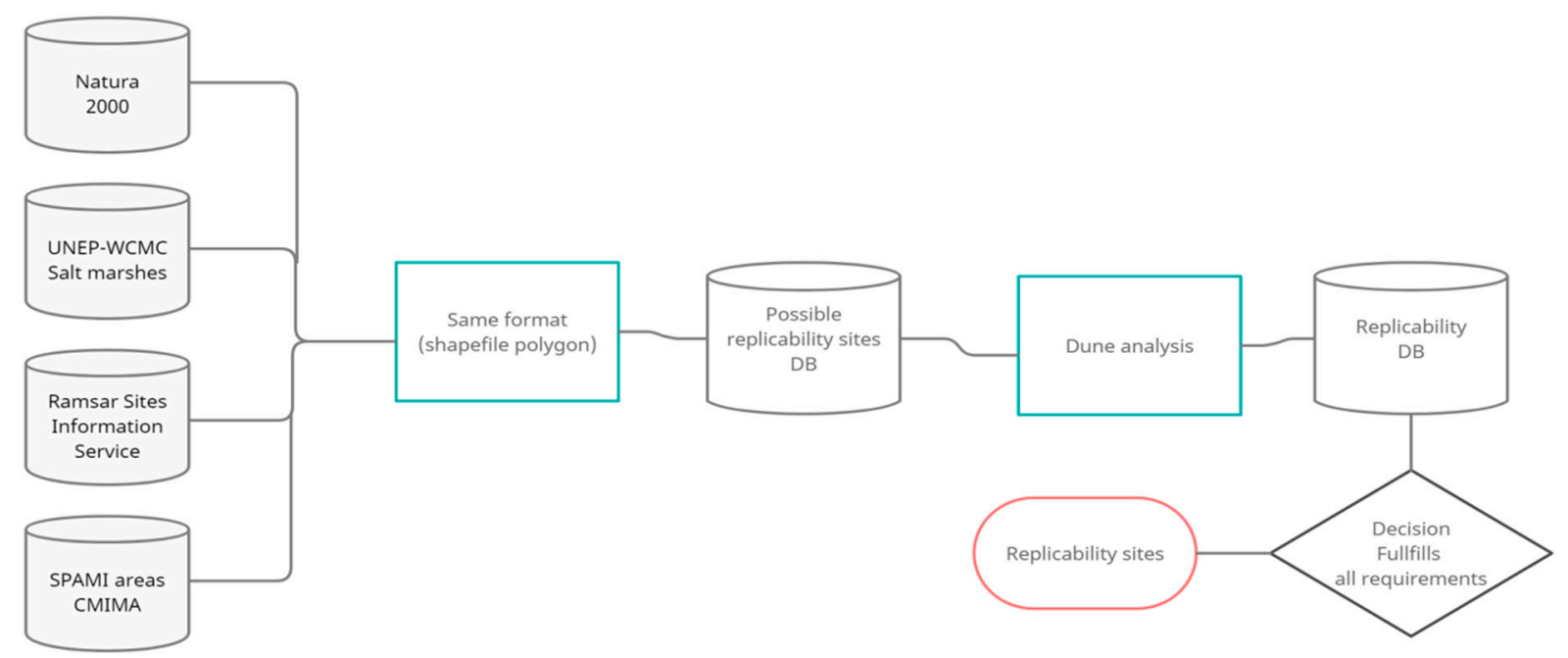

Figure 2. Conceptual scheme of the methodology followed. Source: ewn elaboration.

\section{Results and Discussion}

\subsection{The Natura 2000 Network in the Area of the European Mediterranean and the Black Sea}

In the Natura 2000 network database, 131 sites located on the European Mediterranean coast, the Black Sea, and Portugal were identified that meet all or some of the conditions and attributes of the Regional Park of the Salinas and Arenales of San Pedro del Pinatar, always from the point of view of conservation. That is, coastal lagoons/marshes, wetlands and/or salt structures currently active or inactive but easily recoverable, and coastal beaches and dunes with or without the presence of seagrass meadows on the nearby and underlying marine platform.

After analysing the conditions for the replicability of some of the four actions contemplated in this research study, 26 sites were eliminated that, although being marshes or other types of coastal wetland, do not have salt structuresor dune ridges, and, consequently, do not meet the conditions for the replicability of any of the four actions that are proposed as replicable. It should be noted that Malta also has some active salt flats [42], such as the Bugibba salt flats, but this site was dismissed because it is in an excessively urban environment in which there is no beachor, of course, a dune ridge; and also the historic Qbajjar salt flats, which are more than 2000 years old and dug directly into the sandstone of a fossil beach, which today is about $3 \mathrm{~m}$ above sea level.

Thus, after this initial screening, 105 sites were selected in which one or more of the four actions considered can be replicated (Appendix A and Figure 3). Of these, 26 do not have any other protection figure apart from belonging to the Natura 2000 network. 
Forty-five are, in addition to the Natura 2000 network, Ramsar sites, 62 are ZEPIM sites, and in 28 cases both figures overlap.

By country, Italy (IT) is by far the country with the most sites in the Natura 2000 network in which one or more project actions can be carried out (43 sites). Spain (ES) has 19 sites, in France (FR) 14 sites were located, Greece (GR) has 11 sites, in Portugal (PT) there are 6 sites, Croatia (HR) has 5 sites, and in Bulgaria (BG) 4 sites were located. Finally, in Estonia (SI), Romania (RO), and Cyprus (CY), one site was located in each of them (Appendix A).

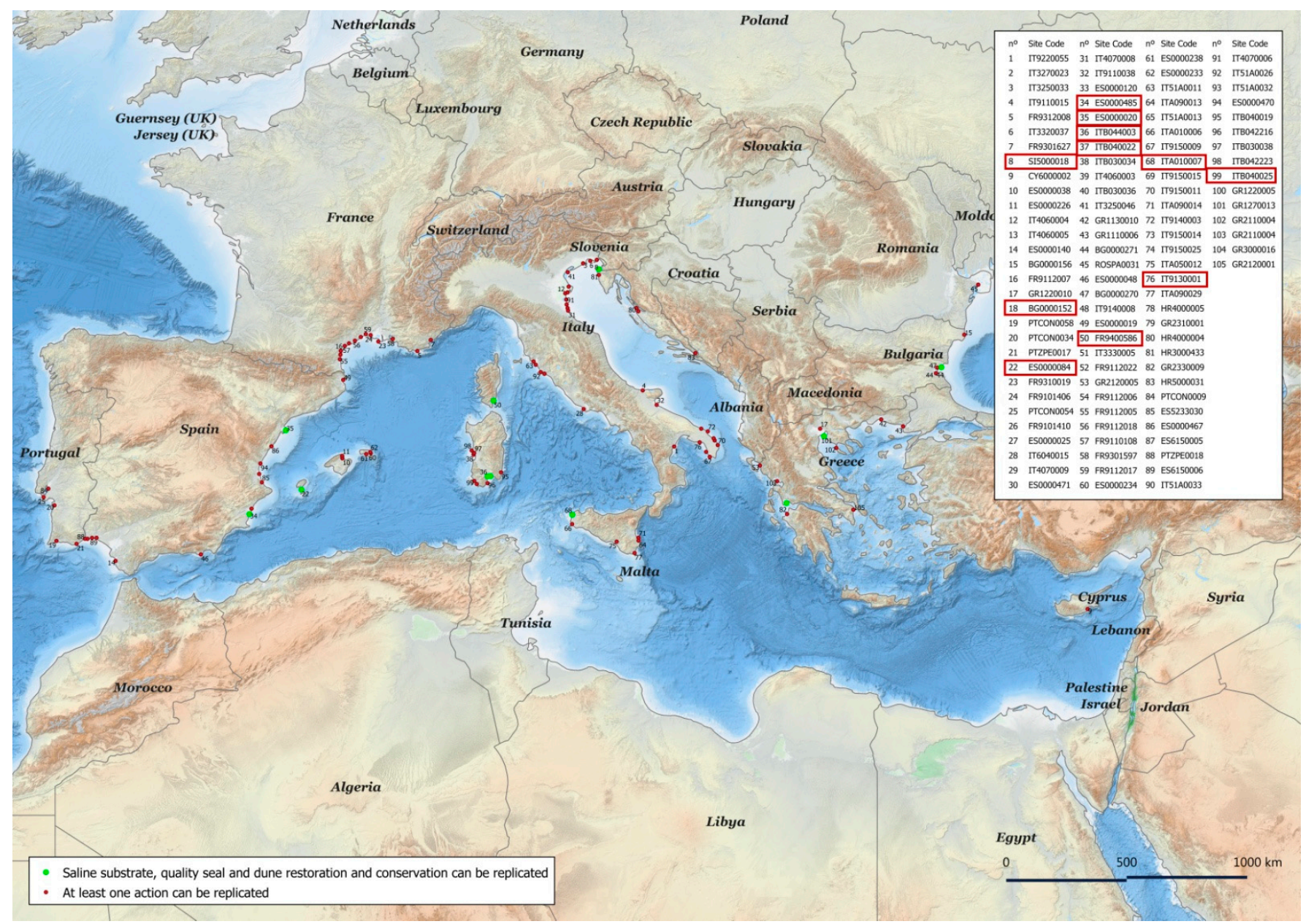

Figure 3. Sites of the Natura 2000 network and location of the 11 sites where the hillocks repair actions with a saline substrate, quality sealing and dune restoration, and conservation can be replicated. The boxed codes correspond to the 11 most favourable replicability sites. Source: own elaboration.

\subsection{Replicability}

Although there are numerous scientific articles that offer methodologies and proposals for actions to be carried out in places with similar environmental characteristics, there are not so many that describe actions developed in LIFE projects and specifically address their replicability and transferability to other projects that contain related environmental improvement objectives $[43,44]$. In this sense, it is necessary to search for projects with similar objectives in order to establish replicable actions and obtain a certain guarantee of the expected results. On the other hand, when its intention is to find out the scope of the transferability of a project, geography as a discipline and its currently most common work tools, such as geographic information systems (GIS), facilitate the search for locations with similar environmental patterns [45]. 
The analysis of the possibilities of replication of the actions of the aforementioned project showed that the dune restoration and conservation actions (sand collectors, control of exotic species, and revegetation) could be replicated in 103 of the 105 selected sites (Appendix A). Only two sites lack a dune ridge: Saline di Priolo, a small salty lagoon in southwestern Sicily in which at some point in the past there was a small saline installation, and Paludi presso il Golfo di Manfredonia, some salt pans located in a small inland lake separated from the Adriatic Sea by just over $2 \mathrm{~km}$, which is completely urbanized today. According to Irene Prisco et al. [46], various regulatory and management tools are commonly used to prevent the negative effects of human trampling on sand dune habitats, but few studies have attempted to assess the effects of walks on the vegetation of the dunes. Several studies have highlighted the value of the ecosystem and the diversity of these habitats, threats, vulnerability, and the need for urgent conservation actions. Among other authors, Bonari et al. [47] provided examples of restoration and effective management. In addition, Bezzi et al. [48] developed a coastal dune management geodatabase, while Pinna et al. [49] applied sand trap systems to replant key dune species with the help of fences and boardwalks to reduce human trampling.

Of these 103 sites with the possibility of dune restoration and conservation, in 62 this action could be supported with the collection of banquettes of seagrasses for their protection against maritime storms [50-52], since in front of the coast of these sites there are oceanic Posidonia meadows or other phanerogams capable of generating banquettes that can be used for the protection of the dune front.

On the other hand, the actions of the repair of hillocks with a saline substrate and implementation of a quality seal in the production of salt could only be replicated in 24 sites where saltwork structures with current activity (industrial or artisanal) were located, or even sites with recently inactive saltworks, meaning that the salt structures are still in good condition and could eventually be used again for the production of salt. In this sense, the sites with salt flats located in this study differ from those mentioned in the "guidelines for the environmental management of salt flats in the Mediterranean and the Black Sea" [19], which include a list of the most recently located salt flats in the Mediterranean and the Black Sea, in which there are 80 salt flats, not including those in Portugal, a country in which we located two salt flats. Of the 80 salt flats, the document considers 37 (13 more than those mentioned in this study, or 15 if we subtract the two in Portugal) to be active. But it was found that, for example, some of the salt flats that were counted in Spain are salt flats that had been abandoned for a long time [53,54], and, in some cases, as occurs in the site of Lo Poyo in the Mar Menor, it is a saline wetland where salt activity was never exerted; so given the discrepancies with the list of salt flats presented in the aforementioned document, and as long as an in-depth review of the salt sites is not carried out, updating and preparing a new list of industrial and artisanal salt flats, active and not active in the Mediterranean and the Black Sea, we could consider the sites located in this study as valid.

Regarding the 24 salt flat sites located in our research study, in 11 of them the replication of the repair actions of hillocks with a saline substrate and a quality seal can be accompanied by those of the restoration and conservation of dunes and protection of dunes through the collection of gorse of phanerogams. That is, there are 11 sites where the four proposed actions can be replicated, the location of which is shown in the following cartography (Figure 3).

To determine if conservation actions were carried out in the selected sites, equal to or similar to those contemplated in this project, and, therefore, if replicability would be repetitive, a search was carried out of the LIFE projects and their general objectives developed at different sites (Table 1).

It was verified that conservation projects linked to the LIFE program were carried out in 18 sites with proposals for actions that are in some way related to the proposals in this study. In two of those sites there were 2 and 3 linked projects. In another 7 sites it is possible that projects were developed, perhaps not linked to the LIFE program, or perhaps, for which information was not found (sometimes the projects that were found developed 
actions that are very different from those contemplated and listed here). Therefore, in principle, these are very suitable sites for the replicability of the actions of this project. In some cases, all the actions could be replicated, as in the Stagno di Santa Caterina site on the island of Sardinia, one of the most favourable places due to its similarity with the surroundings of the Regional Park of Salinas and Arenales of San Pedro del Pinatar, since it has active salt flats, dune ridges in the process of erosion, and oceanic Posidonia meadows that generate a large number of banquettes. In fact, among the activities of the LIFE-Salinas Project, a visit to the Stagno di Santa Caterina site is planned to explore the possibility of collaboration with its managers and to transfer and replicate the actions set out in this paper. In addition, the sites located in Portugal, Ria Formosa and Sapais de Castro Marim, which despite being close to the Atlantic meet Mediterranean environmental and climatic conditions, are conducive to replicating the repair of hillocks with a saline substrate, implementation of a quality seal, and dune restoration and conservation; but it would be little or not at all viable for the protection of the dune ridge with tufts of seagrasses.

Sousa et al. [55], when studying long-term land use change in Ria Formosa, argued that in areas of high conservation value, new policies that stimulate the development of an ecosystem approach to economic activities should be considered. According to these authors, aquaculture simultaneously improves regional environmental status and sustainable socioeconomic development.

In other cases, actions would only be feasible in the salt flats, such as at the Salinas di Trapani site, which is without an appreciable dune ridge, and at the Marais et zones humides liÚs Ó l'Útang de Berre site in France. Likewise, at the Embouchure du Stabiaccu, Domaine Public Maritime et îlot Ziglione site on the island of Corsica (with inactive but recoverable salt pans), actions on dunes could be replicated.

Of the sites where projects had been developed, 7 (4 in Italy, 2 in France, and 1 in Bulgaria) were co-participants in the same project, the LIFE MC SALT, whose main objective was "conservation, management, and rehabilitation of active salt flats, dunes, and coastal wetlands", and in which actions similar to those proposed in this paper had been developed. However, it was not possible to verify that the hillock repair had been carried out with a saline substrateor that a quality seal had been implemented or that the dune ridge had been protected with seagrass tops. In this sense, they are also sites where at least these three actions could be replicated.

In Limnothalassa Angelochoriou (Greece), the LIFE 09/NAT/E/000343 project (2010-2015) also developed actions, in some cases, similar to those proposed in this paper, but it did not it develop actions to restore hillocks with a salt substrateor implement a quality seal for the salt produced or protect the dune ridge with banquettes. The situation is similar in Seoveljske soline" (Slovenia), where the LIFE 09/NAT/SI/000376-MANSALT project (2010-2019) had as objectives (i) to establish control over the water regime of the salt flat and restore degraded areas, (ii) raise awareness about the importance of traditional salt production, which preserves nature and allows sustainable development of the local community, and (iii) present a model of good practice on the use of traditional methods in the reconstruction of the salt mine, that are closely related to many of the objectives of our LIFE-Salinas project but none of the four actions proposed in this research study are exactly considered as replicable and would greatly improve the rest of the actions of restoration and environmental conservation.

In Spain, the LIFE09 NAT/ES/000520 (LIFE-Delta Lagoon) project, developed between 2010 and 2014, carried out actions quite similar to those proposedin this paper (Table 1), but as in the rest of the projects found, it did not contemplate the recovery of hillocks with a salt substrate or the implementation of a quality seal for the salt produced, since its objective in the old San Antonio salt flats was only to recover the connectivity of the salt ponds. There were also no actions on the dunes, so the replicability of the actions of this project is also feasible. In the other 8 remaining sites, the objectives and actions of the developed projects are further from the replicable actions proposed, so they are sites with many possibilities of replication of the actions proposed here. 
Among the projects prior to LIFE-Salinas that had generated replicability through their actions, we can mention some whose methodologies inspired actions carried out in our LIFE-Salinas project. Thus, for example, in a Mediterranean environmental context, we can cite the project "MC-SALT—Environmental Management and Restoration of Mediterranean Salt Works and Coastal Lagoons", with actions in Italy, France, and Bulgaria over the period (2013-2016), and with the objective of preserving native species and dunes. This project had a precedent in the LIFE Valli di Comacchio [56], focused on the ecological restoration and conservation of habitats in the salt flats and SCI of the same name, but in the case of the LIFE MC-SALT, for the first time the optimization of the water flow in the salt flats was contemplated to improve their performance.

Outside the Mediterranean area, the ARCOS LIFE 2014-2018 project focused on actions aimed at improving the state of conservation of the dune ecosystems of the Cantabrian coast (northern Spain), starting from a fragile situation due to both natural and anthropic threats [57]. Its actions included the elimination of non-native tree cover, the elimination of exotic species, the planting of dune species, and the installation of sand traps for the development of the dunes. These last two actions are key to proper management of Mediterranean dunes [58] and are usually carried out in any project that includes dune restoration.

Table 1. Sites of the Natura 2000 network with industrial or artisanal salt flats and projects developed in them related to one or more of the actions proposed in this study.

\begin{tabular}{|c|c|c|c|c|}
\hline \multirow{2}{*}{ Site Code } & \multirow{2}{*}{ Sites } & \multirow{2}{*}{ Condition * } & \multicolumn{2}{|c|}{ Related Life Projects } \\
\hline & & & Project & Main Objective \\
\hline \multirow{3}{*}{ BG0000270 } & \multirow{3}{*}{ Atanasovsko ezero } & \multirow{3}{*}{$\mathrm{A}$} & $\begin{array}{l}\text { LIFE17 NAT/BG/000277 } \\
(2010-2014)\end{array}$ & $\begin{array}{l}\text { Improving the management of the } \\
\text { coastal wetland complex }\end{array}$ \\
\hline & & & $\begin{array}{l}\text { LIFE17 NAT /BG/000362 } \\
\text { (2012-2018) }\end{array}$ & $\begin{array}{l}\text { Establishing a functional and efficient } \\
\text { structure for the management of the } \\
\text { water of the coastal area }\end{array}$ \\
\hline & & & $\begin{array}{l}\text { LIFE17 NAT/BG/000558 } \\
(2018-2024)\end{array}$ & $\begin{array}{l}\text { Improving the state of coastal lagoons } \\
\text { and their long-term conservation }\end{array}$ \\
\hline ES0000140 & Bay of Cádiz & $\mathrm{R}$ & $\begin{array}{l}\text { LIFE Litoral Cádiz. LIFE03 } \\
\text { NAT/E/000054 } \\
(2003-2006)\end{array}$ & $\begin{array}{l}\text { Restoration, conservation, and } \\
\text { management actions in coastal } \\
\text { ecosystems (wetlands, dunes) }\end{array}$ \\
\hline \multirow[t]{2}{*}{ FR9310019 } & \multirow[t]{2}{*}{ Camargue } & \multirow[t]{2}{*}{ A } & $\begin{array}{c}\text { LIFE MC SALT } \\
\text { LIFE 10/NAT/IT/000256 } \\
(2011-2015)\end{array}$ & $\begin{array}{l}\text { Conservation, management, and } \\
\text { rehabilitation of active salt flats, } \\
\text { dunes, and coastal wetlands }\end{array}$ \\
\hline & & & $\begin{array}{c}\text { LIFE + ENVOLL LIFE } 12 \\
\text { NAT / FR/000538 (2013-2018) }\end{array}$ & $\begin{array}{c}\text { Protection of seabirds in saline } \\
\text { environments }\end{array}$ \\
\hline GR2310001 & $\begin{array}{c}\text { Delta Acheloou, } \\
\text { Limnothalassa } \\
\text { Mesolongiou- } \\
\text { Aitolikou, Ekvoles } \\
\text { Evinou, Nisoi } \\
\text { Echinades, Nisos } \\
\text { Petalas }\end{array}$ & $\mathrm{A}$ & $\begin{array}{l}\text { LIFE95 NAT/GR/001111 } \\
\text { (1995-1999) }\end{array}$ & $\begin{array}{c}\text { Contribute to the conservation of the } \\
\text { slender curlew (Numenius } \\
\text { temuirostris) }\end{array}$ \\
\hline ES0000020 & Delta de l'Ebre & $\mathrm{A} / \mathrm{R}$ & $\begin{array}{l}\text { LIFE09 NAT/ES/000520 } \\
\text { LIFE-Delta Lagoon } \\
\quad(2010-2014)\end{array}$ & $\begin{array}{l}\text { Improving the ecological status and } \\
\text { hydrological connectivity of the } \\
\text { Alfacada lagoon. Mitigating the effects } \\
\text { of the coastal regression. Improving } \\
\text { the status of priority habitats and } \\
\text { species. } \\
\text { Improving the ecological status and } \\
\text { hydrological connectivity of the old } \\
\text { San Antonio salt flats (La Tancada } \\
\text { lagoon area) } \\
\text { Developing monitoring and } \\
\text { dissemination measures of the } \\
\text { ecological values of the restored areas. }\end{array}$ \\
\hline
\end{tabular}


Table 1. Cont.

\begin{tabular}{|c|c|c|c|c|}
\hline \multirow{2}{*}{ Site Code } & \multirow{2}{*}{ Sites } & \multirow{2}{*}{ Condition * } & \multicolumn{2}{|c|}{ Related Life Projects } \\
\hline & & & Project & Main Objective \\
\hline FR9400586 & $\begin{array}{l}\text { Embouchure du } \\
\text { Stabiaccu, Domaine } \\
\text { Public Maritime et } \\
\text { îlot Ziglione }\end{array}$ & $\mathrm{R}$ & - & - \\
\hline FR9112006 & Etang de Lapalme & $\mathrm{R}$ & $\begin{array}{l}\text { LIFE + ENVOLL LIFE 12 } \\
\text { NAT/FR/000538 (2013-2018) }\end{array}$ & $\begin{array}{l}\text { Preparatory actions in the Sigean salt } \\
\text { flats and conservation of the old } \\
\text { marshes }\end{array}$ \\
\hline FR9112007 & $\begin{array}{l}\text { Étangs du } \\
\text { Narbonnais }\end{array}$ & $\mathrm{A} / \mathrm{R}$ & $\begin{array}{l}\text { LIFE + ENVOLL LIFE 12 } \\
\text { NAT/FR/000538 (2013-2018) }\end{array}$ & $\begin{array}{l}\text { Preparatory actions in the Sigean salt } \\
\text { flats and conservation of the old } \\
\text { marshes }\end{array}$ \\
\hline ES0000485 & $\begin{array}{l}\text { Mata and Torrevieja } \\
\text { Lagoons }\end{array}$ & A & $\begin{array}{c}\text { LIFE Salinas } \\
\text { Torre Vieja } \\
\text { LIFE 08/NAT/E/000077 } \\
(2010-2011)\end{array}$ & $\begin{array}{l}\text { Creation of a decantation and } \\
\text { ecological recovery circuit for the La } \\
\text { Mata and Torrevieja lagoons }\end{array}$ \\
\hline GR1220005 & $\begin{array}{l}\text { Limnothalassa } \\
\text { Angelochoriou }\end{array}$ & A & $\begin{array}{c}\text { LIFE 09/NAT/E/000343 } \\
(2010-2015)\end{array}$ & $\begin{array}{l}\text { Improving the conservation status of } \\
\text { coastal lagoons, salty steppes, and } \\
\text { beds of posidonia (Posidonia } \\
\text { oceanica), as well as priority seabird } \\
\text { species such as the curl (Numenius } \\
\text { tenuirostris) and the pygmy } \\
\text { cormorant (Microcarbo pygmeus) }\end{array}$ \\
\hline FR9301597 & $\begin{array}{l}\text { Marais et zones } \\
\text { hümides liÚs Ô } \\
\text { l'Útang de Berre }\end{array}$ & & - & - \\
\hline IT9110038 & $\begin{array}{l}\text { Paludi presso il Golfo } \\
\text { di Manfredonia }\end{array}$ & A & $\begin{array}{c}\text { LIFE 09/NAT/E/000150 } \\
(2010-2019)\end{array}$ & $\begin{array}{l}\text { Improving the conservation status of } \\
\text { priority wetlands, lagoons, coastal } \\
\text { dunes, and saline steppes }\end{array}$ \\
\hline FR9101406 & Petite Camargue & A & $\begin{array}{c}\text { LIFE MC SALT } \\
\text { LIFE 10/NAT/FR/000256 } \\
(2011-2016) \\
\end{array}$ & $\begin{array}{l}\text { Conservation, management and } \\
\text { rehabilitation of active salt flats, } \\
\text { dunes, and coastal wetlands }\end{array}$ \\
\hline BG0000152 & Pomoriysko ezero & $\mathrm{A}$ & $\begin{array}{c}\text { LIFE MC SALT } \\
\text { LIFE 10/NAT/BG/000256 } \\
(2011-2016)\end{array}$ & $\begin{array}{l}\text { Conservation, management and } \\
\text { rehabilitation of active salt flats, } \\
\text { dunes, and coastal wetlands }\end{array}$ \\
\hline PTZPE0017 & Ria Formosa & $\mathrm{A}$ & $?$ & - \\
\hline IT4070007 & Salina di Cervia & A & $\begin{array}{c}\text { LIFE MC SALT } \\
\text { LIFE 10/NAT/IT/000256 } \\
(2011-2016)\end{array}$ & $\begin{array}{l}\text { Conservation, management, and } \\
\text { rehabilitation of active salt flats, } \\
\text { dunes, and coastal wetlands }\end{array}$ \\
\hline ITA090013 & Saline di Priolo & $\mathrm{R}$ & $\begin{array}{c}\text { LIFE MC SALT } \\
\text { LIFE 10/NAT/IT/000256 } \\
(2011-2016) \\
\end{array}$ & $\begin{array}{l}\text { Conservation, management, and } \\
\text { rehabilitation of active salt flats, } \\
\text { dunes, and coastal wetlands }\end{array}$ \\
\hline ITA010007 & Saline di Trapani & A & - & - \\
\hline FR9312008 & $\begin{array}{l}\text { Salins d'Hybres et } \\
\text { des Pesquiers }\end{array}$ & $\mathrm{R}$ & $\begin{array}{l}\text { LIFE MC SALT } \\
\text { LIFE 10/NAT/FR/000256 } \\
(2011-2016)\end{array}$ & $\begin{array}{l}\text { Conservation, management, and } \\
\text { rehabilitation of active salt flats, } \\
\text { dunes, and coastal wetlands }\end{array}$ \\
\hline PTZPE0018 & $\begin{array}{l}\text { Sapais de Castro } \\
\text { Marim }\end{array}$ & $\mathrm{A}$ & - & - \\
\hline SI5000018 & Seoveljske soline & A & $\begin{array}{l}\text { LIFE 09/NAT/SI/000376- } \\
\text { MANSALT } \\
(2010-2019)\end{array}$ & $\begin{array}{l}\text { Establish control over the water } \\
\text { regime of the saline and restore } \\
\text { degraded areas. } \\
\text { Raise awareness about the importance } \\
\text { of traditional salt production, which } \\
\text { preserves nature and allows } \\
\text { sustainable development of the local } \\
\text { community. } \\
\text { Present a model of good practices on } \\
\text { the use of traditional methods in the } \\
\text { reconstruction of the saline. }\end{array}$ \\
\hline
\end{tabular}


Table 1. Cont.

\begin{tabular}{ccccc}
\hline Site Code & Sites & Condition * & Project & Related Life Projects \\
\cline { 4 - 5 } ES0000084 & $\begin{array}{c}\text { Ses Salines d'Eivissa } \\
\text { i Formentera }\end{array}$ & A & - & Main Objective \\
\hline ITB044003 & Stagno di Cagliari & A & $\begin{array}{c}\text { LIFE96 NAT/IT/003106 } \\
\text { (1997-2002) }\end{array}$ & $\begin{array}{c}\text { Restore the environmental quality of } \\
\text { the Stagno di Cagliari. } \\
\text { Elimination of landfills. } \\
\text { Cessation of the entry of wastewater. }\end{array}$ \\
\hline ITB040022 & $\begin{array}{c}\text { Stagno di } \\
\text { Molentargius e } \\
\text { territori limitrofi }\end{array}$ & A & $\begin{array}{c}\text { LIFE 10/NAT/IT/000256 } \\
\text { (2011-2016) }\end{array}$ & $\begin{array}{c}\text { Conservation, management, and } \\
\text { rehabilitation of active salt flats, } \\
\text { dunes, and coastal wetlands }\end{array}$ \\
\hline ITB042223 & $\begin{array}{c}\text { Stagno di Santa } \\
\text { Caterina }\end{array}$ & A & - & - \\
\hline
\end{tabular}

* Note: Salinas: A = active; $\mathrm{R}$ = recoverable. In Bold: sites where the four proposed actions can be replicated. Source: own elaboration.

According to Sun et al. [59], coordination between different scales and administrative levels, as well as international cooperation, should be fundamental strategies for improving the management and conservation of wetlands.Likewise, according to Gumiero et al. [60], the successful management of natural resources is much more than developing good science, it requires working together with the many agents and/or actors involved, and above all sharing knowledge through diverse case studies.

\section{Conclusions}

LIFE projects require the dissemination of actions and their replication at the European level. In this context, the LIFE-Salinas Project has always sought to implement a large part of its actions. The methodology used in its nature conservation actions is transferable and replicable in a large part of the Mediterranean area, and transferability is optimal in coastal places with dune systems and with saline exploitations, especially if they are located within the Natura 2000 network. Beyond the economic and social importance of Mediterranean salt pans, this research study highlights the importance of maintaining their activity, since it is key in the conservation of coastal wetlands.

The creation and use of spatial databases constitute a key tool when analysing the replicability of actions of environmental improvement projects such as the one at hand. In addition to providing information, they allow working with different variables in a unified way.

In short, the actions of the project contemplated in this paper can be replicated for a large number of sites in the Natura 2000 network in the Mediterranean area. Among these actions, it is worth highlighting, as a novel contribution, the repair of hillocks with a salt substrate, which improves the production of salt and the habitat of seabirds, and the implementation of a quality seal for the production of salt.

Author Contributions: Conceptualization, D.I.-M., F.B.-S., G.B.-P. and R.G.-M.; methodology, D.I.-M. and F.B.-S.; formal analysis, D.I.-M., G.B.-P. and R.G.-M.; investigation, D.I.-M., F.B.-S., G.B.-P. and R.G.-M.; data curation, D.I.-M. and R.G.-M.; writing-original draft preparation, F.B.-S., D.I.-M., G.B.-P. and R.G.-M.; writing-review and editing, D.I.-M., F.B.-S., G.B.-P. and R.G.-M.; supervision, R.G.-M. All authors have read and agreed to the published version of the manuscript.

Funding: This research was funded by the Environment and Climate Action Program (LIFE), managed by the European Commission, grant number LIFE17 NAT/ES/000184, and the APC was funded by the same project. The LIFE-SALINAS Project, Conservation of habitats and aquatic birds in the LIC (Community Interest Area) and ZEPA (Special Areas for the Protection for Birds) ES0000175 "Salinas y Arenales de San Pedro del Pinatar" (southeastern Spain), is based on sustainable development, since it improves the conservation of priority fauna species and habitats in the European Union, in addition to enhancing the ecosystem services by increasing production and improving the quality of salt. More information about the project can be found at: https: / / lifesalinas.es/ (accessed on 31 May 2021). 
Data Availability Statement: Not applicable.

Acknowledgments: This article was written thanks to the co-financing of LIFE funds from the European Union, through the LIFE17/ES/000184 Project, Conservation of habitats and aquatic birds in the LIC, and SPA ES0000175 "Salinas and Arenales of San Pedro del Pinatar"(LIFE-SALINAS). The authors want to thank anonymous reviewers for their suggestions, which have helped to significantly improve the manuscript.

Conflicts of Interest: The authors declare no conflict of interest.

\section{Appendix A}

Table A1. Sites of the Natura 2000 network. Characteristics and replicability.

\begin{tabular}{|c|c|c|c|c|c|c|c|}
\hline \multirow{2}{*}{ Sites } & \multirow{2}{*}{ Code } & \multirow{2}{*}{ Ha } & \multirow{2}{*}{ Ramsar } & \multirow{2}{*}{ SPAMI } & \multicolumn{3}{|c|}{ Replicability } \\
\hline & & & & & 1 & 2 & 3 \\
\hline Aiguamolls de l'Alt Empordà & ES0000019 & $10,850.6$ & & & & $X$ & \\
\hline Alimini & IT9150011 & 3719.6 & & $X$ & & $X$ & $X$ \\
\hline Alykes Larnakas & CY6000002 & 1568.6 & $x$ & $x$ & & $x$ & $\mathrm{X}$ \\
\hline $\begin{array}{c}\text { Amvrakikos Kolpos, Limnothalassa } \\
\text { Katafourko Kai Korakonisia }\end{array}$ & GR2110004 & $23,227.2$ & & $x$ & & $x$ & $x$ \\
\hline Atanasovsko ezero & BG0000270 & 7218.2 & $X$ & $X$ & $X$ & $X$ & $X$ \\
\hline Bahía de Cádiz & ES0000140 & $10,550.7$ & $X$ & & $X$ & $X$ & \\
\hline Basse plaine de l'Aude & FR9110108 & 4839.2 & & & & $x$ & \\
\hline $\begin{array}{l}\text { Bosco Pantano di Policoro e Costa Ionica Foce } \\
\text { Sinni }\end{array}$ & IT9220055 & 1798.7 & & $x$ & & $X$ & $x$ \\
\hline Camargue & FR9310019 & 220,509 & $X$ & & $X$ & $X$ & \\
\hline Capo di Pula & ITB042216 & 1582.1 & & & & $X$ & \\
\hline Complexe lagunaire de Salses-Leucate & FR9112005 & 7668.1 & & & & $x$ & \\
\hline Comporta & PTCON0034 & $32,149.2$ & $x$ & & & $X$ & \\
\hline D'Addaia a s'Albufera & ES0000233 & 2817.1 & & $x$ & & $x$ & $\mathrm{X}$ \\
\hline $\begin{array}{c}\text { Delta Acheloou, Limnothalassa } \\
\text { Mesolongiou-Aitolikou, Ekvoles Evinou, } \\
\text { Nisoi Echinades, Nisos Petalas }\end{array}$ & GR2310001 & $35,730.0$ & & $x$ & $x$ & $x$ & $\mathrm{X}$ \\
\hline $\begin{array}{l}\text { Delta Axiou-Loudia-Aliakmona-Alyki } \\
\text { Kitrous }\end{array}$ & GR1220010 & $28,926.6$ & $x$ & $x$ & & $x$ & $\mathrm{X}$ \\
\hline Delta de l'Ebre & ES0000020 & $48,627.5$ & $x$ & $x$ & $X$ & $x$ & $\mathrm{X}$ \\
\hline Delta del Po & IT3270023 & $24,988.8$ & & $X$ & & $X$ & $\mathrm{X}$ \\
\hline Delta Dunrii i Complexul Razim-Sinoie & ROSPA0031 & 507,816 & $x$ & $x$ & & $x$ & $\mathrm{X}$ \\
\hline Delta Evrou & GR1110006 & $12,397.7$ & $x$ & $x$ & & $x$ & $x$ \\
\hline Delta Neretve & HR5000031 & $23,836.8$ & & $x$ & & $x$ & $\mathrm{X}$ \\
\hline Duna del Lago di Burano & IT51A0032 & 98.2 & & & & $x$ & \\
\hline Duna e Lago di Lesina-Foce del Fortore & IT9110015 & 9845.0 & & $x$ & & $x$ & $\mathrm{X}$ \\
\hline Ekvoles Kalama & GR2120001 & 8637.7 & & $x$ & & $x$ & $\mathrm{X}$ \\
\hline Embouchure de l'Argens & FR9301627 & 1379.5 & $x$ & & & $x$ & \\
\hline $\begin{array}{l}\text { Embouchure du Stabiaccu, Domaine Public } \\
\text { Maritime et îlot Ziglione }\end{array}$ & FR9400586 & 195.8 & & & $x$ & $x$ & \\
\hline Est et sud de BÚziers & FR9112022 & 6085.8 & & & & $x$ & \\
\hline Estuario do Tejo & PTCON0009 & $44,132.7$ & & & & $x$ & \\
\hline Etang de Lapalme & FR9112006 & 3911.9 & & & $\mathrm{X}$ & $X$ & \\
\hline Étang de Mauguio & FR9112017 & 7020.0 & & & & $x$ & \\
\hline Étang de Thau et lido de SPte Ó Agde & FR9112018 & 7750.7 & & & & $X$ & \\
\hline
\end{tabular}


Table A1. Cont.

\begin{tabular}{|c|c|c|c|c|c|c|c|}
\hline \multirow{2}{*}{ Sites } & \multirow{2}{*}{ Code } & \multirow{2}{*}{ Ha } & \multirow{2}{*}{ Ramsar } & \multirow{2}{*}{ SPAMI } & \multicolumn{3}{|c|}{ Replicability } \\
\hline & & & & & 1 & 2 & 3 \\
\hline Étangs du Narbonnais & FR9112007 & $12,257.2$ & $X$ & & $X$ & $X$ & \\
\hline Étangs palavasiens & FR9101410 & 6599.5 & $x$ & $x$ & & $x$ & $x$ \\
\hline FernÒo Ferro/Lagoa de Albufeira & PTCON0054 & 4330.5 & $x$ & & & $x$ & \\
\hline Foce dell'Isonzo-Isola della Cona & IT3330005 & 2668.5 & & $X$ & & $x$ & $x$ \\
\hline Lago di Burano (b) & IT51A0033 & 490.0 & & & & $x$ & \\
\hline Laguna di Caorle-Foce del Tagliamento & IT3250033 & 4377.6 & & $X$ & & $X$ & $\mathrm{X}$ \\
\hline Laguna di Marano e Grado & IT3320037 & $16,363.4$ & $x$ & $X$ & & $X$ & $\mathrm{X}$ \\
\hline Laguna di Orbetello & IT51A0026 & 3698.4 & & & & $X$ & \\
\hline Laguna di Venezia & IT3250046 & $55,148.0$ & $x$ & & & $x$ & \\
\hline Lagunas de la Mata y Torrevieja & ES0000485 & 3742.9 & $X$ & $X$ & $x$ & $X$ & $\mathrm{X}$ \\
\hline l'Albufera & ES0000471 & $29,338.5$ & $X$ & & & $X$ & \\
\hline L'Albufereta & ES0000226 & 444.2 & $X$ & $X$ & & $X$ & $\mathrm{X}$ \\
\hline Le Cesine & IT9150014 & 648.0 & & $X$ & & $X$ & $\mathrm{X}$ \\
\hline $\begin{array}{l}\text { Limnes Vistonis, Ismaris-Limnothalasses } \\
\text { Porto Lagos, Alyki Ptelea, Xirolimni, Karatza }\end{array}$ & GR1130010 & $17,740.8$ & $x$ & $x$ & & $x$ & $x$ \\
\hline Limnothalassa Angelochoriou & GR1220005 & 373.6 & & $X$ & $X$ & $X$ & $\mathrm{X}$ \\
\hline Limnothalassa Kotychi-Alyki Lechainon & GR2330009 & 2350.6 & & $X$ & & $X$ & $\mathrm{X}$ \\
\hline Litorale di Gallipoli e Isola S. Andrea & IT9150015 & 7016.4 & & $\mathrm{X}$ & & $\mathrm{X}$ & $\mathrm{X}$ \\
\hline Litorale di Ugento & IT9150009 & 7255.1 & & & & $X$ & \\
\hline Mandra-Poda & BG0000271 & 6146.6 & $x$ & $x$ & & $X$ & $x$ \\
\hline $\begin{array}{c}\text { Marais et zones humides liÚs Ó l'Útang de } \\
\text { Berre }\end{array}$ & FR9301597 & 1559.6 & & & $x$ & $x$ & \\
\hline Marismas de Isla Cristina & ES6150005 & 2499.9 & & & & $x$ & \\
\hline Marismas del Odiel & ES0000025 & 6626.9 & $x$ & & & $X$ & \\
\hline $\begin{array}{c}\text { Marismas del río Piedras y Flecha del } \\
\text { Rompido }\end{array}$ & ES6150006 & 2411.6 & & & & $x$ & \\
\hline Marjal de la Safor & ES5233030 & 1247.6 & & $x$ & & $x$ & $x$ \\
\hline Marjal dels Moros & ES0000470 & 627.9 & & $X$ & & $X$ & $X$ \\
\hline Ortazzo, Ortazzino, Foce del Torrente Bevano & IT4070009 & 1254.7 & $x$ & $X$ & & $X$ & $X$ \\
\hline Padule della Trappola, Bocca d'Ombrone & IT51A0013 & 490.0 & & & & $X$ & \\
\hline Padule di Diaccia Botrona & IT51A0011 & 1349.2 & & & & $x$ & \\
\hline Paludi di Capo Feto e Margi Span & ITA010006 & 351.0 & & $\mathrm{X}$ & & $x$ & $x$ \\
\hline Paludi presso il Golfo di Manfredonia & IT9110038 & $14,470.3$ & $x$ & $x$ & $x$ & & $x$ \\
\hline $\begin{array}{l}\text { Pantani della Sicilia sud-orientale, Morghella, } \\
\text { di Marzamemi, di Punta Pilieri e Vendicari }\end{array}$ & ITA090029 & 3575.5 & & $x$ & & $x$ & $x$ \\
\hline Parco Nazionale del Circeo & IT6040015 & $22,205.0$ & $x$ & & & $x$ & \\
\hline Petite Camargue & FR9101406 & $34,410.6$ & $X$ & & $x$ & $X$ & \\
\hline Pialassa dei Piomboni, Pineta di Punta Marina & IT4070006 & 463.9 & & $X$ & & $X$ & $\mathrm{X}$ \\
\hline Pineta di Cervia & IT4070008 & 194.2 & $X$ & $X$ & & $X$ & $\mathrm{X}$ \\
\hline Pomoriysko ezero & BG0000152 & 922.1 & $X$ & $X$ & $x$ & $X$ & $X$ \\
\hline Prat de Cabanes i Torreblanca & ES0000467 & 1945.5 & & & & $\mathrm{X}$ & \\
\hline Privlaka-Ninski zaljev-Ljubaki zaljev & HR4000005 & 2001.0 & & $x$ & & $X$ & $x$ \\
\hline Promontorio, dune e zona umida di Porto Pino & ITB040025 & 2707.0 & & & & $X$ & \\
\hline Punta Entinas-Sabinar & ES0000048 & 1980.9 & $x$ & $x$ & & $x$ & $x$ \\
\hline Ria de Alvor & PTCON0058 & 1459.4 & $x$ & & & $x$ & \\
\hline
\end{tabular}


Table A1. Cont.

\begin{tabular}{|c|c|c|c|c|c|c|c|}
\hline \multirow{2}{*}{ Sites } & \multirow{2}{*}{ Code } & \multirow{2}{*}{ Ha } & \multirow{2}{*}{ Ramsar } & \multirow{2}{*}{ SPAMI } & \multicolumn{3}{|c|}{ Replicability } \\
\hline & & & & & 1 & 2 & 3 \\
\hline Ria Formosa & PTZPE0017 & $23,362.6$ & $x$ & & $X$ & $X$ & \\
\hline $\begin{array}{l}\text { Sacca di Goro, Po di Goro, Valle Dindona, Foce } \\
\text { del Po di Volano }\end{array}$ & IT4060005 & 4867.7 & $x$ & $x$ & & $x$ & $x$ \\
\hline S'Albufera de Mallorca & ES0000038 & 2207.0 & $X$ & $X$ & & $X$ & $x$ \\
\hline S'Albufera des Grau & ES0000234 & 2544.9 & & $X$ & & $X$ & $\mathrm{X}$ \\
\hline Salina di Cervia & IT4070007 & 1095.2 & $x$ & $\mathrm{X}$ & $X$ & & $\mathrm{X}$ \\
\hline Salinas de Santa Pola & ES0000120 & 2511.4 & $x$ & $x$ & & $x$ & $x$ \\
\hline Saline di Augusta & ITA090014 & 63.6 & & $x$ & & $X$ & $X$ \\
\hline Saline di Trapani & ITA010007 & 1010.1 & & $X$ & $X$ & $X$ & $X$ \\
\hline Salins d'HyPres et des Pesquiers & FR9312008 & 961.1 & $X$ & & $x$ & $X$ & \\
\hline Sapais de Castro Marim & PTZPE0018 & 2154.0 & & & $x$ & $x$ & \\
\hline Seoveljske soline & SI5000018 & 968.8 & $x$ & $x$ & $x$ & $x$ & $x$ \\
\hline Ses Salines d'Eivissa i Formentera & ES0000084 & $16,488.1$ & $X$ & $X$ & $X$ & $X$ & $\mathrm{X}$ \\
\hline Shablenski ezeren kompleks & BG0000156 & 3177.0 & $X$ & $X$ & & $X$ & $x$ \\
\hline Son Bou i barranc de sa Vall & ES0000238 & 1177.7 & & $X$ & & $X$ & $\mathrm{X}$ \\
\hline Stagni di Colostrai e delle Saline & ITB040019 & 1154.8 & & & & $x$ & \\
\hline Stagni e Saline di Punta della Contessa & IT9140003 & 2861.7 & & $x$ & & $x$ & $x$ \\
\hline Stagno di Cabras & ITB030036 & 4810.0 & $X$ & & & $X$ & \\
\hline Stagno di Cagliari & ITB044003 & 3769.5 & $x$ & $x$ & $x$ & $x$ & $x$ \\
\hline Stagno di Corru S'Ittiri & ITB030032 & 5730.0 & $\mathrm{X}$ & & & $X$ & \\
\hline Stagno di Mistras di Oristano & ITB030034 & 1626.5 & $x$ & & & $x$ & \\
\hline Stagno di Molentargius e territori limitrofi & ITB040022 & 1279.7 & $\mathrm{X}$ & $\mathrm{X}$ & $x$ & $x$ & $\mathrm{X}$ \\
\hline $\begin{array}{c}\text { Stagno di Putzu Idu (Salina Manna e Pauli } \\
\text { Marigosa) }\end{array}$ & ITB030038 & 599.4 & & & & $x$ & \\
\hline Stagno di Santa Caterina & ITB042223 & 627.5 & & & $X$ & $X$ & \\
\hline Torre Colimena & IT9130001 & 2682.6 & & $x$ & & $X$ & $x$ \\
\hline Torre Guaceto & IT9140008 & 548.8 & & $\mathrm{X}$ & & $X$ & $x$ \\
\hline Torre Manfria, Biviere e Piana di Gela & ITA050012 & $25,166.5$ & & $X$ & & $X$ & $x$ \\
\hline Torre Veneri & IT9150025 & 1743.2 & & & & $X$ & \\
\hline UÜe Mirne & HR3000433 & 125.5 & & $X$ & & $X$ & $\mathrm{X}$ \\
\hline Valle Bertuzzi, Valle Porticino-CanneviP & IT4060004 & 2689.0 & $x$ & $\mathrm{X}$ & & $\mathrm{X}$ & $x$ \\
\hline Velo i Malo Blato & HR4000004 & 661.2 & & $\mathrm{X}$ & & $X$ & $\mathrm{X}$ \\
\hline $\begin{array}{l}\text { Vene di Bellocchio, Sacca di Bellocchio, Foce } \\
\text { del Fiume Reno, Pineta di Bellocchio }\end{array}$ & IT4060003 & 2242.4 & $x$ & $x$ & & $x$ & $x$ \\
\hline Ygrotopoi Neas Fokaias & GR1270013 & 422.4 & & $x$ & & $x$ & $\mathrm{X}$ \\
\hline $\begin{array}{c}\text { Ygrotopos Ekvolon Kalama Kai Nisos } \\
\text { Prasoudi }\end{array}$ & GR2120005 & 8649.1 & & $x$ & & $x$ & $x$ \\
\hline Ygrotopos Schinia & GR3000016 & 2102.3 & & $X$ & & $X$ & $x$ \\
\hline
\end{tabular}

Note: In this table, the sites that have conditions for the replicability of one or more actions of the project have been marked. Replicable actions: 1 = saline substrate in hillocks and a quality seal (meaning that there are active saline structures at present or those that were active until recently on which this action can be implemented; 2 = sand collectors, removal of exotic species, and revegetation (meaning that it has dune/beach systems); 3 = protection of the dune ridge by means of seagrass tops (meaning that there are seagrass meadows that can provide seagrass tops).Source: own elaboration.

\section{References}

1. Millennium Ecosystem Assessment (MEA). Ecosystems and Human Well-Being; Island Press: Washington, DC, USA, 2005.

2. Barbier, E.B.; Hacker, S.D.; Kennedy, C.; Koch, E.W.; Stier, A.C.; Silliman, B.R. The value of estuarine and coastal ecosystem services. Ecol. Monogr. 2011, 81, 169-193. [CrossRef] 
3. Zedler, J.B.; Kercher, S. WETLAND RESOURCES: Status, Trends, Ecosystem Services, and Restorability. Annu. Rev. Environ. Resour. 2005, 30, 39-74. [CrossRef]

4. Kim, S.G. The evolution of coastal wetland policy in developed countries and Korea. Ocean Coast. Manag. 2010, 53, 562-569. [CrossRef]

5. Cools, J.; Johnston, R.; Hattermann, F.; Douven, W.; Zsuffa, I. Tools for wetland management: Lessons learnt from a comparative assessment. Environ. Sci. Policy 2013, 34, 138-145. [CrossRef]

6. Morzaria-Luna, H.N.; Castillo-López, A.; Danemann, G.D.; Turk-Boyer, P. Conservation strategies for coastal wetlands in the Gulf of California, Mexico. Wetl. Ecol. Manag. 2013, 22, 267-288. [CrossRef]

7. Zhao, Q.; Bai, J.; Huang, L.; Gu, B.; Lu, Q.; Gao, Z. A review of methodologies and success indicators for coastal wetland restoration. Ecol. Indic. 2016, 60, 442-452. [CrossRef]

8. Qu, Y.; Luo, C.; Zhang, H.; Ni, H.; Xu, N. Modeling the wetland restorability based on natural and anthropogenic impacts in Sanjiang Plain, China. Ecol. Indic. 2018, 91, 429-438. [CrossRef]

9. Verhoeven, J.T. Wetlands in Europe: Perspectives for restoration of a lost paradise. Ecol. Eng. 2013, 66, 6-9. [CrossRef]

10. Rubec, C.D.A.; Hanson, A.R. Wetland mitigation and compensation: Canadian experience. Wetl. Ecol. Manag. 2009, 17, 3-14. [CrossRef]

11. Burgin, S. 'Mitigation banks' for wetland conservation: A major success or an unmitigated disaster? Wetl. Ecol. Manag. 2009, 18, 49-55. [CrossRef]

12. Brinson, M.M.; Eckles, S.D. U.S. Department of Agriculture conservation program and practice effects on wetland ecosystem services: A synthesis. Ecol. Appl. 2011, 21, S116-S127. [CrossRef]

13. Neuman, A.D.; Belcher, K.W. The contribution of carbonbased payments to wetland conservation compensation on agricultural landscapes. Agric. Syst. 2011, 104, 75-81. [CrossRef]

14. Blackwell, M.; Pilgrim, E.S. Ecosystem services delivered by small-scale wetlands. Hydrol. Sci. J. 2011, 56, 1467-1484. [CrossRef]

15. Bassi, N.; Kumar, M.D.; Sharma, A.; Pardha-Saradhi, P. Status of wetlands in India: A review of extent, ecosystem benefits, threats and management strategies. J. Hydrol. Reg. Stud. 2014, 2, 1-19. [CrossRef]

16. Sun, G.; Hallema, D.; Asbjornsen, H. Ecohydrological processes and ecosystem services in the Anthropocene: A review. Ecol. Process. 2017, 6, 1-9. [CrossRef]

17. Gallego-Fernandez, J.B.; García-Mora, M.R.; García-Novo, F. Small wetlands lost: A biological conservation hazard in Mediterranean landscapes. Environ. Conserv. 1999, 26, 190-199. [CrossRef]

18. Calhoun, A.J.; Mushet, D.M.; Bell, K.P.; Boix, D.; Fitzsimons, J.A.; Isselin-Nondedeu, F. Temporary wetlands: Challenges and solutions to conserving a 'disappearing'ecosystem. Biol. Conserv. 2017, 211, 3-11. [CrossRef]

19. Angeler, D.G. Management and conservation of temporary ponds: Opportunities and challenges in the new millennium. In International Conference on Temporary Ponds; Proceedings \& Abstracts; Consell Insular de Menorca, Recerca Maó: Menorca, Spain, 2009; Volume 14, pp. 299-306.

20. Moss, B.; Hering, D.; Green, A.J.; Aidoud, A.; Becares, E.; Beklioglu, M.; Bennion, H.; Boix, D.; Brucet, S.; Carvalho, L.; et al. Climate Change and the Future of Freshwater Biodiversity in Europe: A Primer for Policy-Makers. Freshw. Rev. 2009, 2, 103-130. [CrossRef]

21. McGreavy, B.; Calhoun, A.; Jansujwicz, J.; Levesque, V. Citizen science and natural resource governance: Program design for vernal pool policy innovation. Ecol. Soc. 2016, 21. [CrossRef]

22. Walton, M. Biodiversity conservation and the Yellow Sea Large Marine Ecosystem project. J. Korean Soc. Mar. Environ. Energy 2010, 13, 335-340.

23. Hahn, T.; Olsson, P.; Folke, C.; Johansson, K. Trust-building, knowledge generation and organizational innova-tions: The role of a bridging organization for adaptive comanagement of a wetland landscape around Kristianstad, Sweden. Hum. Ecol. 2006, 34, 573-592. [CrossRef]

24. Ibrahim, I.; Aziz, N.A. The Roles of International NGOs in the Conservation of Bio-Diversity of Wetlands. Procedia Soc. Behav. Sci. 2012, 42, 242-247. [CrossRef]

25. Trokanova, L. CANCELLED: EU LIFE PROGRAMME Contributing for Nature Conservation in Practice. In Proceedings of the 5th European Congress of Conservation Biology, Jyväskylä, Finland, 12-15 June 2018.

26. Imperial, M.T. Analyzing Institutional Arrangements for Ecosystem-Based Management: Lessons from the Rhode Island Salt Ponds SAM Plan. Coast. Manag. 1999, 27, 31-56. [CrossRef]

27. Rodríguez Estrella, T. Geología de la Región de Murcia. In El medio Físico de la Región de Murcia; García, C.C., Ed.; Universidad de Murcia: Murcia, Spain, 2006; pp. 11-46.

28. Romero Díaz, A.; Belmonte Serrato, F. Los paisajes Geomorfológicos de la Región de Murcia como recurso turístico. Cuad. Tur. 2002, 103-122. Available online: https://revistas.um.es/turismo/article/view/21931 (accessed on 5 February 2021).

29. Lillo Carpio, M. Geomorfología litoral del Mar Menor. In Papeles de Geografía; Universidad de Murcia: Murcia, Spain, 1978; pp. 9-53.

30. Ballesteros Pelegrín, G.A. El Parque Regional de las Salinas y Arenales de San Pedro del Pinatar. In Actividades Humanas y Conservación; Universidad de Murcia: Murcia, Spain, 2014; p. 367.

31. Mitsch, W.J.; Gosselink, J.G. Wetlands, 4th ed.; John Wiley \& Sons: Hoboken, NJ, USA, 2007; p. 582. 
32. Munar, R.I.; Xavier, F.; Prieto, J.A.M. Efectos de la retirada de bermas vegetales de Posidonia oceanica sobre playas de las islas Baleares: Consecuencias de la presión turística. Investig. Geogr. 2005, 57, 40-52. [CrossRef]

33. Oro, D.; Ruxton, G.D. The formation and growth of seabird colonies: Audouin's gull as a case study. J. Anim. Ecol. 2002, 70, 527-535. [CrossRef]

34. Bertolero, A.; Genovart, M.; Martínez-Abraín, A.; Molina, B.; Mouriño, J.; Oro, D.; Tavecchia, G. Gaviotas Cabecinegra, Picofina, de Audouin y Tridáctila, y Gavión Atlántico en España. Población en 2007 y Método de Censo; SEO/BirdLIFE: Madrid, Spain, 2008.

35. Hébert, P.N. Effect of Fog on Herring Gull (Larus argentatus) Chick Survivorship and Parental Foraging Patterns. Colon. Waterbirds 1987, 10, 103. [CrossRef]

36. Bolton, M. Determinants of Chick Survival in the Lesser Black-Backed Gull: Relative Contributions of Egg Size and Parental Quality. J. Anim. Ecol. 1991, 60, 949. [CrossRef]

37. Kilpi, M.; Hillström, L.; Lindström, K. Egg-size variation and reproductive success in the Herring Gull Lams argentatus: Adaptive or constrained size of the last egg? IBIS 1996, 138, 212-217. [CrossRef]

38. Monaghan, P.; Nager, R.G.; Houston, D.C. The price of eggs: Increased investment in egg production reduces the offspring rearing capacity of parents. Proc. Biol. Sci. 1998, 265, 1731-1735. [CrossRef]

39. Prieto, J.; Jover, L.; Ruiz, X. Efectos del aporte de refugios sobre la supervivencia de pollos de Gaviota de Audouin. Sci. Mar. 2003, 67, 103-108. [CrossRef]

40. Cornelis, W.M.; Gabriels, D. A simple low-cost sand catcher for wind-tunnel simulations. Earth Surf. Process. Landf. 2003, 28, 1033-1041. [CrossRef]

41. McOwen, C.J.; Weatherdon, L.V.; Van Bochove, J.-W.; Van, B.J.-W.; Blyth, S.; Zockler, C.; Stanwell-Smith, D.; Kingston, N.; Martin, C.S.; Spalding, M.; et al. A global map of saltmarshes. Biodivers. Data J. 2017, 5, e11764. [CrossRef]

42. Schembri, J.A. Coastal Land Use in the Maltese Islands: A Descriptionand Appraisal. Ph.D. Thesis, Durham University, Durham, UK, August 2003. Available online: http:/ / etheses.dur.ac.uk/4417/ (accessed on 20 March 2021).

43. Liberti, F.; Pistolesi, V.; Massoli, S.; Bartocci, P.; Bidini, G.; Fantozzi, F. i-REXFO LIFE: An innovative business model to reduce food waste. Energy Procedia 2018, 148, 439-446. [CrossRef]

44. Vagnoni, E.; Atzori, A.S.; Molle, G. Sheeptoship Life: Integration of Environmental Strategies with Rural Development Policies. In Planning, Nature and Ecosystems Services; Gargiulo, C., Zoppi, C., Eds.; Federico II Open Access University Press: Naples, Italy, 2019; pp. 366-374. [CrossRef]

45. Goodchild, M.F. Geographic information systems and science: Today and tomorrow. Ann. GIS 2009, 15, 3-9. [CrossRef]

46. Prisco, I.; Acosta, A.T.R.; Stanisci, A. A bridge between tourism and nature conservation: Boardwalks effects on coastal dune vegetation. J. Coast. Conserv. 2021, 25, 1-12. [CrossRef]

47. Bonari, G.; Těšitel, J.; Migliorini, M.; Angiolini, C.; Protano, G.; Nannoni, F.; Schlaghamerský, J.; Chytrý, M. Conservation of the Mediterranean coastal pine woodlands: How can management support biodiversity? For. Ecol. Manag. 2019, 443, 28-35. [CrossRef]

48. Bezzi, A.; Pillon, S.; Martinucci, D.; Fontolan, G. Inventory and conservation assessment for the management of coastal dunes, Veneto coasts, Italy. J. Coast. Conserv. 2018, 22, 503-518. [CrossRef]

49. Pinna, M.S.; Bacchetta, G.; Orrù, H.; Cogoni, D.; Sanna, A.; Fenu, G. Results of the Providune project: Restoration of the “Coastal dunes with Juniperus spp." priority habitat in Sardinia. Plant. Sociol. 2017, 73-84. [CrossRef]

50. Gacia, E.; Granata, T.; Duarte, C.M. An approach to measurement of particle flux and sediment retention within seagrass (Posidonia oceanica) meadows. Aquat. Bot. 1999, 65, 255-268. [CrossRef]

51. Spalding, M.D.; Ruffo, S.; Lacambra, C.; Meliane, I.; Hale, L.Z.; Shepard, C.C.; Beck, M.W. The role of ecosystems in coastal protection: Adapting to climate change and coastal hazards. Ocean Coast. Manag. 2014, 90, 50-57. [CrossRef]

52. Vuik, V.; Jonkman, S.; Borsje, B.W.; Suzuki, T. Nature-based flood protection: The efficiency of vegetated foreshores for reducing wave loads on coastal dikes. Coast. Eng. 2016, 116, 42-56. [CrossRef]

53. Dias, M.P. Use of Salt Ponds by Wintering Shorebirds throughout the Tidal Cycle. Waterbirds 2009, 32, 531-537. [CrossRef]

54. Dias, M.P.; Lecoq, M.; Moniz, F.; Rabaça, J.E. Can Human-made Saltpans Represent an Alternative Habitat for Shorebirds? Implications for a Predictable Loss of Estuarine Sediment Flats. Environ. Manag. 2014, 53, 163-171. [CrossRef]

55. Sousa, C.A.; Cunha, M.E.; Ribeiro, L. Tracking 130 years of coastal wetland reclamation in Ria Formosa, Portugal: Opportunities for conservation and aquaculture. Land Use Policy 2020, 94, 104544. [CrossRef]

56. Pellizzari, M.; Barbieri, C.; Caramori, G.; Pagnoni, G.; Piccoli, F. La vegetazione della Salina di Comacchio (Ferrara, Parco del Delta del Po): Ripristino ecologico e conservazione degli hábitat. Fitosociologia 2007, 44, 77-82.

57. Fernández Iglesias, E.; Ramos-Guajardo, A.B.; González-Rodríguez, G.; Marquínez, J. Role of littoral processes on the sand movement in the Northern Spanish coast by fitting regression models. In Proceedings of the 3rd International Conference in Econometrics and Statistics (EcoStats 2019), Taichung, Taiwan, 25-27 June 2019.

58. Van Der Meulen, F.; Salman, A.H.P.M. Management of Mediterranean coastal dunes. Ocean Coast. Manag. 1996, 30, 177-195. [CrossRef]

59. Sun, Z.; Sun, W.; Tong, C.; Zeng, C.; Yu, X.; Mou, X. China's coastal wetlands: Conservation history, implementation efforts, existing issues and strategies for future improvement. Environ. Int. 2015, 79, 25-41. [CrossRef]

60. Gumiero, B.; Mant, J.; Hein, T.; Elso, J.; Boz, B. Linking the restoration of rivers and riparian zones/wetlands in Europe: Sharing knowledge through case studies. Ecol. Eng. 2013, 56, 36-50. [CrossRef] 